\title{
POSSIBILITIES FOR APPLICATION OF DOCUMENT CAMERAS AND WEBCAMS IN THE LECTURE HALLS AND LABORATORIES OF THE UNIVERSITIES
}

\author{
Vanya Stoykova, Zlatin Zlatev, Stanka Baycheva \\ Trakia University of Stara Zagora, Faculty of Technics and Technologies \\ 38 Graf Ignatiev str., 8602, Yambol, Bulgaria, \\ e-mail: vanya.stoykova@trakia-uni.bg
}

\begin{abstract}
This report examines and analyzes the possibilities of using document cameras in the learning process, their use as a tool for visualization in the auditoriums, laboratories and universities as tools for increasing the interest and activity of students. An overview of the possibilities of using Web-cameras as document cameras is made as well. The advantages and disadvantages in the application of these devices primarily as a learning tool are represented by analysis, which compares the key parameters of the document cameras and webcams.
\end{abstract}

Keywords: Innovative Educational Technologies, Document Camera, Webcam.

\section{INTRODUCTION}

The document camera (DC) is widely used in many American and European schools, universities and research institutes [3,6, 9, 22, 23]. Below are given some examples of its application in teaching and research in Bulgarian universities.

The increasing popularity of document cameras is due to their ease of use, convenience, flexibility, dynamism, attractiveness and great opportunities for visualization of teaching materials, trial, 3D objects, etc., in the auditoriums and classrooms.

In [2] researches and standards related to strategies for increasing the success of students are cited. The author summarizes his findings as follows: "The key decisions in educational organizations and institutions should consider document camera as standard technology solution that provides students a better visualization of the educational content". However, the use of a document camera should not be an end in itself. It is necessary to take into account all the modern interactive teaching methods in DC's application in higher school educational process.

There are a number of works, related to the use of more common and more affordable Webcameras and iPads for visualization of the educational content - function for which are basically designed document cameras.

In scientific publications [17] and Internet forums and blogs, teachers share their experience in using Webcams and iPads [21, 24, 25, 28, 29] as document cameras, mainly for visualization of the educational content.

In $[5,14]$ the authors present their experience in implementing interactive teaching tools in Zambia. They propose the use of Web-cameras for visualization of the educational content. The application of document cameras is unknown to the teachers of this country. Problems encountered in the use of web cameras lead to serious difficulties and reluctance to implement such technical means in training.

At the same time, as highlighted above, due to all the advantages and potentialities of DCs, they are widely used in universities in the US and Europe.

Considering Bulgarian higher education, DSs should be used not only sporadically in some universities but taking into account all possibilities to support the learning process, to find a widespread use in auditoriums and laboratories.

IRTIIL Vol. 4, No. 2, 2016 ISSN 1314-8788 (print), ISSN 1314-8796 (online), doi: 10.15547/artte.2016.02.005 
To build document cameras with Web-camera (or iPad) in the above developments are used both standard and non-standard tools such as tripods for cameras, stands from bedside lamps, as well as own developments made with 3D printers. The authors recommend the use of HD-cameras with high resolution as they converge on the characteristics of the document cameras used in practice.

The aim of this report is to examine the possibility of use of Web-camera as a document camera by comparing the basic parameters of the devices.

The best practices for the application of DC in the university auditoriums and laboratories are presented, as well as suggestions for some less popular applications.

\section{EXPOSURE}

The report presents a comparison of technical parameters of the high-end, mid-range document camera and HD Web camera used in most developments related to its application as DC.

Some typical applications of document cameras unrelated to their application as a learning tool are presented and analyzed as well.

\subsection{Comparative analysis of webcams and document cameras}

Table 1 shows the parameters of the two models DC Epson DC-11 and Epson DC-06 and a webcam. Epson DC-11 is a document camera of high-end class, which is placed on top of the popular charts of these devices [20].

Table 1. Comparison of technical parameters of Webcam and document cameras

\begin{tabular}{|c|c|c|c|c|}
\hline \multicolumn{2}{|c|}{ Parameter } & Epson DC-11 (ELPDC11) & $\begin{array}{l}\text { Epson DC-06 } \\
\text { (ELPDC06) }\end{array}$ & $\begin{array}{l}\text { Webcam Logitech } \\
\text { QuickCam Pro } 9000\end{array}$ \\
\hline \multicolumn{2}{|c|}{ Sensor } & $1 / 4 \mathrm{CMOS}$ & $1 / 3 \mathrm{CMOS}$ & CMOS \\
\hline \multicolumn{2}{|c|}{$\begin{array}{l}\text { Maximum optical } \\
\text { resolution }\end{array}$} & $2592 \times 1944$ & $1024 \times 768$ & $1600 \times 1200$ \\
\hline \multicolumn{2}{|c|}{ Video sensor } & $5 \mathrm{MP}$ & $1 \mathrm{MP}$ & $2 \mathrm{MP}$ \\
\hline \multicolumn{2}{|c|}{ Optical Zoom } & $\begin{array}{ll}2 x & \text { (XGA/WXGA output) } \\
1.9 x & \text { (SXGA output) }\end{array}$ & $1 x$ & No data \\
\hline \multicolumn{2}{|c|}{ Digital Zoom } & $10 x$ & $4 x$ & No data \\
\hline \multirow{2}{*}{ Interface } & Input & VGA, Composite, SD card & - & - \\
\hline & Output & VGA, USB & USB & USB \\
\hline \multicolumn{2}{|c|}{ Power supply } & AC-DC $12 \mathrm{~V}$ adapter & 5V viaUSB power & 5V viaUSB power \\
\hline \multicolumn{2}{|c|}{ Internal memory } & $\begin{array}{l}\text { 1 GB internal } \\
\text { SD card slot }\end{array}$ & - & - \\
\hline \multicolumn{2}{|c|}{ Microscope adapter } & Yes & No & No \\
\hline \multicolumn{2}{|c|}{ Frame Rate } & $30 \mathrm{fps}$ & $15 \mathrm{fps}$ & $30 \mathrm{fps}$ \\
\hline \multicolumn{2}{|c|}{ Autofocus } & Yes & Yes & Yes \\
\hline \multicolumn{2}{|c|}{ Built-in microphone } & Yes & Yes & Yes \\
\hline \multicolumn{2}{|c|}{ Illumination System } & Yes & Yes & No \\
\hline \multicolumn{2}{|c|}{$\begin{array}{l}\text { Integration to Interactive } \\
\text { Whiteboard }\end{array}$} & Yes & Yes & Yes \\
\hline \multicolumn{2}{|c|}{$\begin{array}{l}\text { Price compared to high- } \\
\text { end document camera }\end{array}$} & $100 \%$ & $39 \%$ & $29 \%$ \\
\hline \multicolumn{2}{|c|}{$\begin{array}{l}\text { Ability to work without a } \\
\text { computer }\end{array}$} & Yes & No & No \\
\hline \multicolumn{2}{|c|}{ Measurement of color } & Yes & No & No \\
\hline \multicolumn{2}{|c|}{$\begin{array}{l}\text { Recognition of bar- and } \\
\text { QR- codes }\end{array}$} & Yes & Yes & Yes \\
\hline \multicolumn{2}{|c|}{$\begin{array}{l}\text { Recognition of object } \\
\text { areas }\end{array}$} & Yes & Yes & Yes \\
\hline
\end{tabular}

IRTTIE Vol. 4, No. 2, 2016 ISSN 1314-8788 (print), ISSN 1314-8796 (online), doi: 10.15547/artte.2016.02.005 


\section{ART'TE

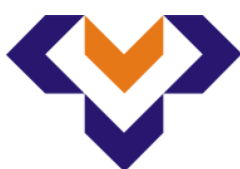 \\ Ipplied Reseitrones in Technics, Technologies and Bductition \\ Journal of the Faculty of Technics and Technologies, Trakia University https://sites.google.com/a/trakia-uni.bg/artte/}

The table shows that the high-end Web-camera approaches the parameters of a document camera from the lower end and its use as a tool for visualization of the educational content in certain cases is justified.

\subsection{Application as a learning tool}

Examples of application of DC in the training of students of technical and humanities have been reported in $[11,12,16,19,26]$. There are also opportunities to integrate DC to interactive whiteboard.

Other examples of using DC as a tool for visualization of the lab results are presented in [1]. An experimental setup consisting of document cameras Epson DC-11, Epson DC-06 and Webcam is used.The video devices are connected to a personal computer and interactive whiteboard Interwrite Dualboard 1279.

An interesting option for online training in the modern versions of Moodle e-course management system, provides the plugin BigBlueButtonBN, which enables sharing of realtime presentations (incl. Whiteboard), audio, video, chat and screen content. Joint video sessions of the teacher and students can be implemented using internet connection and document cameras (Fig. 1). The additional possibility of DC to integrate microscope, recording audio and video and better technical parameters (Table 1) increase the applicability of this tool in Moodle for implementation of distance learning, incl. implementation of virtual laboratories [15] monitoring documents, artifacts, trial (incl. in remote, dangerous or inaccessible environments for students) and to carry out other educational activities in real-time and with the active participation of students.

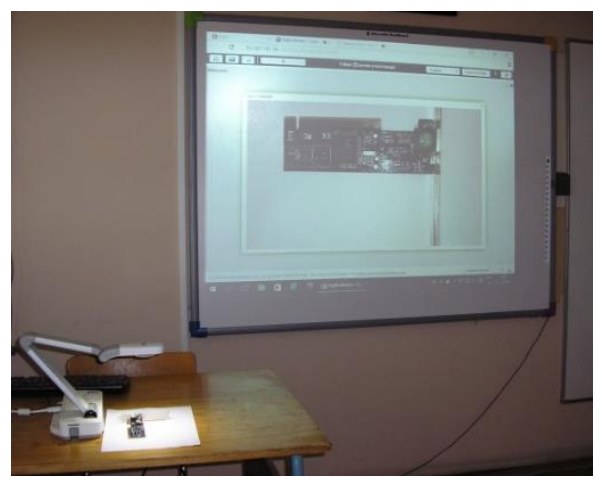

a) Epson DC-11

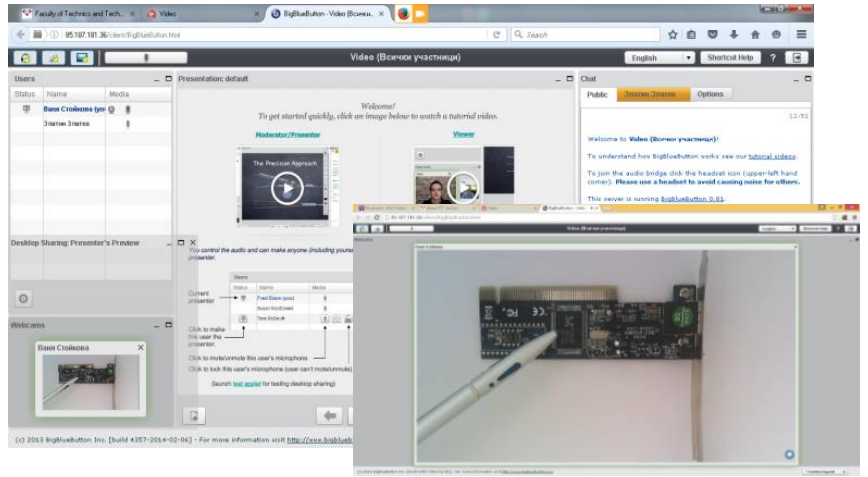

b) "BigBlueButtonBN in e-course "Computer networks"

Figure 1. Application of "BigBlueButtonBN" in MOODLE

\subsection{Recognition of bar code and $Q R$ code}

QR Codes are becoming more widely used in academic activities. One of their attractive applications is presentation of correct answers of a test (Fig. 2), an indication of web-based teaching materials (incl. Video) [13] or additional information. Their use make the presentation of the material attractive for students from the digital generation.

For processing of QR Codes is used online application [10]. The same application can be used in processing of bar-codes. One-dimensional bar-codes have not yet found extensive use in the area of education. 


\section{IRTTIE}

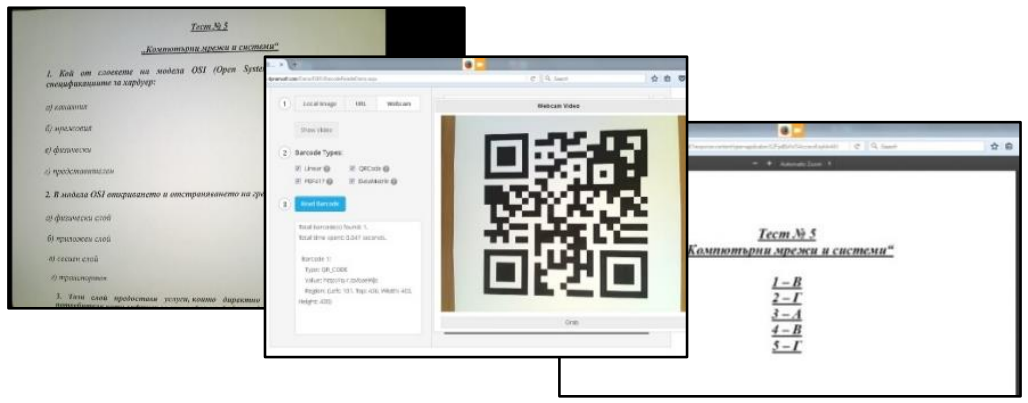

a) recognition of $Q R$-code

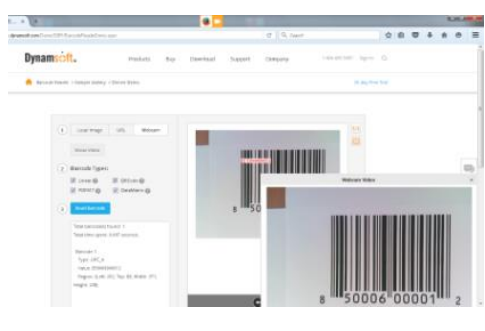

b) recognition of - Barcode

Figure 2. Recognition of Barcode and QR-code

Several experiments have been conducted for recognition of one-dimensional and twodimensional codes with document cameras and Webcams, with the same application, as the results are compared with three video cameras. In all cases the recognition is successful. An impact on the recognition was caused by the light as because of the presence of strong reflections of the object the code is displayed partly from the camera. This disadvantage is removed by proper adjustment of light (Table1) on the subject.

\subsection{Measurement of color}

The use of document camera for measurement the color of the foodstuffs has been the subject of study of teachers and students at the Faculty of Technics and Technologies, Trakia University of Stara Zagora, Bulgaria for several years [7, 18].

The color is an important indicator of the quality of food products. It is directly related with their freshness and storage conditions, which are important both for their good taste and to avoid the development of health hazardous microorganisms and bacteria and is a major indicator when choosing a product from consumers. This makes measurement of color important in training courses in the field of food technology.

Comparative analysis of measuring color with three video cameras is presented in previous studies of authors [1]. A comparison is made with the three video cameras with 24-color pattern and colorimetric sensor. The results show that the high-end document-camera's features are approaching to the color detecting sensor.

\subsection{Recognition of object areas of foodstuffs}

The various parts of the food products in a uniform surface structure are not identical. Through the digital image analysis of the surface color characteristics is possible to process images, such as fat, bone and muscle tissue in meat, cheese and dairy products with mold, areas of bread and mold. In case of objects with complex surface characteristics is appropriate the use of the full spectrum of image instead of the individual components of RGB or another color model.

In previous studies of professors and students from the faculty $[7,18]$ found that using the document camera is appropriate in recognition of object fields of food products, the results are comparable to those obtained with industrial video camera [8]. 


\section{IRTTL $\vee$}

Ipplied Researlohes in Technics, Technologies and Bductition

Journal of the Faculty of Technics and Technologies, Trakia University https://sites.google.com/a/trakia-uni.bg/artte/

\subsection{Measurement of dimensions}

In [4] the authors use a document camera to measure the parameters of the surfaces of machine parts. Described is a study to determine the size of the major diameter of thread (Figure 3). Through the statistical analysis of the results it found that with the camera used are obtained results similar to the measured with a caliper. The latter is evidence to suggest that using the document the camera provides sufficient accuracy in measuring geometric parameters and received uncertainty is commensurate with the uncertainty in contact measurement methods. The authors state they could improve the method for calibration of the camera, which will reduce the uncertainty.

Related to the measurement of dimensions is the publication of other researchers [9]. The authors indicate that basil has a high index of germination, short germination time. To monitor the sprouting process into practice is used software with high cost. The development is related to the study of the influence of the electromagnetic field with power $293 \mathrm{~W}$ and treatment with ultrasound power with $0,5 \mathrm{~W} / \mathrm{cm}^{2}$ on the germination of seeds. For capturing and processing of the images is used open source software and CAD system. The capture of the image of the seeds of basil is realized with a document camera (Figure 4) connected to a personal computer on which is installed that open source software. The authors have chosen to use a document camera with high resolution. The dimensions of measurement of the seeds are set by measuring line, placed next to the object.

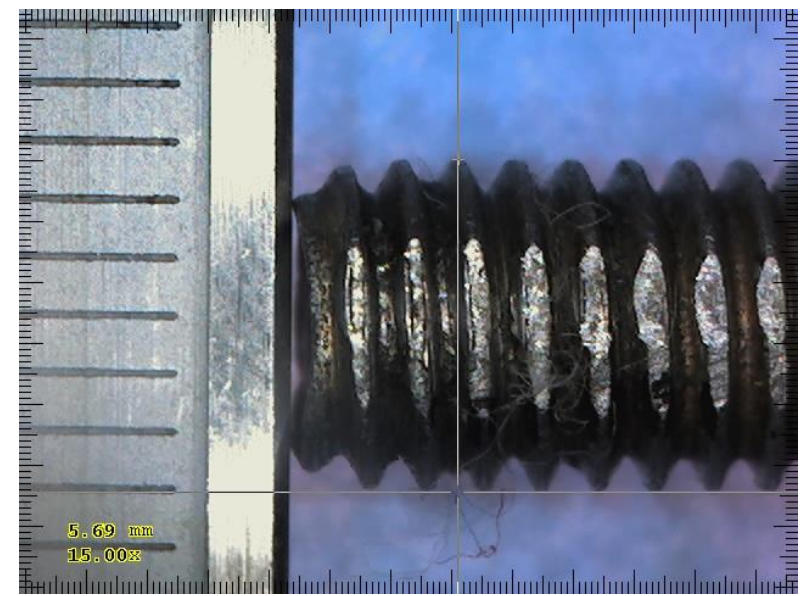

Figure 3. Measurement of the major diameter of thread

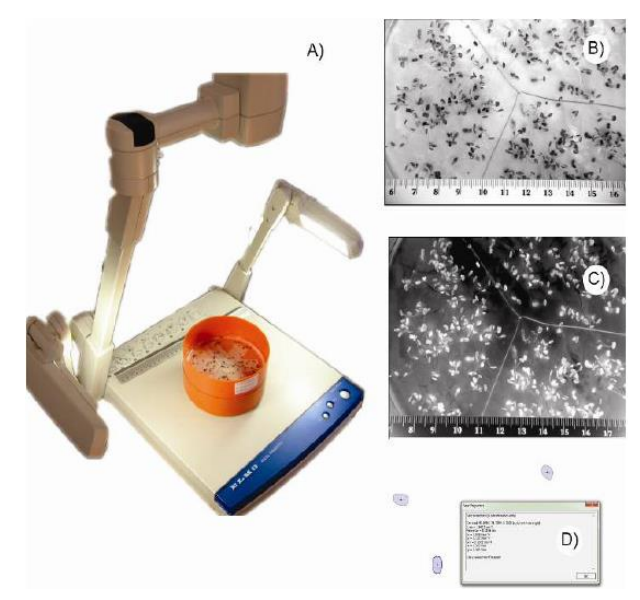

Figure 4. Investigation of germination of seeds of basil with a document camera [9]

\subsection{Application in processing of election documents}

As a non-traditional application of DC can be consider its use for processing of election results. Application of cameras capturing the voters is described in [27].

The application we offer is related to document camera's use instead of a scanner while recording in digital format ( .pdf) of the election protocols. One of the main problems concerning the slow progress of the elections is directly related to the time required to scan all of the pages of election protocols. In many cases, problems related to bilateral printed information and its recognition when scanning arise. Document cameras could be successfully used Instead of scanners. The latter will certainly reduce the time for processing records. The recognition of bar-code, identifying each protocol is discussed above as

IRTTIC Vol. 4, No. 2, 2016 ISSN 1314-8788 (print), ISSN 1314-8796 (online), doi: 10.15547/artte.2016.02.005 


\section{ARTTE $Y$}

Ipplied Researlohes in Technics, Technologies and Bductition

Journal of the Faculty of Technics and Technologies, Trakia University https://sites.google.com/a/trakia-uni.bg/artte/

possible use of the DC. The presented in the report comparative analysis of DC and web cameras and the particular importance of scanned documents, make inappropriate the use of web-cameras or low-end DC.

\section{CONCLUSION}

The document camera has a number of options for visualization of text materials (incl. Represented in the QR code), static and dynamic 3D objects in enlarged audience, including extra zoom, conducting experiments, joint video sessions through the appropriate application systems for e-learning, with the possibility of recording images, audio and video, and more.

The conducted comparative analysis and the discussed good practices, prove that high-end DC can be used for various research - to measure the color, object recognition, determination of size. The last and the aforementioned possibilities of DC makes them essential tool for training in modern of interactive classrooms, auditoriums and laboratories of universities in Bulgaria.

The application of high-end DC in some atypical, non-academic activities is proposed and justified, taking into account their high parameters in terms of resolution and quality of captured images, high-speed when creating graphics and audio-video files and opportunities for recognition of bar and QR code.

The high-end web-cameras are close in their parameters to low-end document-cameras. Their use as a tool for visualization of content and other activities in classrooms, in certain cases, when high quality and accuracy is not required, is justified given their lower cost.

\section{ACKNOWLEDGEMENTS}

The research is supported by the project 2.FTT/ 30.04.2015 „Application of virtual laboratories in the universities".

\section{REFERENCES}

[1] Baycheva S., Z. Zlatev, A. Dimitrova, Investigating the possibilities of document cameras for quality assessment of foodstuffs by measuring of color, ICVL 2016, Romania, ISSN: 1844-8933.

[2] Brooks-Young S., Are document-cameras the next big thing? THE Journal, 34 (6), 2007, pp. 20-21.

[3] Bruder P. Document cameras in the classroom, http://www.njea.org/news-andpublications/njea-review/december-2011/document-camera.

[4] Georgiev G., Z. Zlatev, Comparative analysis for measuring the geometry machine parts, Proceedings of ICTTE 2013, ISSN 1314-9474, pp.49-56.

[5] Haßler, B., Hennessy, S., Lord, T., Cross, A., Jackson, A., Simpson, M. (2011). An investigation of appropriate new technologies to support interactive teaching in Zambian schools (ANTSIT): Final report to DfID. University of Cambridge http://www.educ.cam.ac.uk/centres/cce/initiatives/projects/antsit/DfIDANTSITReport_FIN AL_Low_Bandwidth_1_0_7.pdf.

[6] Hoge R. J., $2010 \bar{A}$ Digital Odyssey: Exploring Document Camera Technology and Computer Self-Efficacy in a Digital Era, (2010), Theses and Capstone Projects, Paper 114.

[7] Kutovancheva, G., Improvement of interactive presentation system with additional device for image recognition. Applied scientific journal Innovation and entrepreneurship, vol. 4, No 1, 2016, ISSN 1314-9253, pp.44-57.

IRTIIE Vol. 4, No. 2, 2016 ISSN 1314-8788 (print), ISSN 1314-8796 (online), doi: 10.15547/artte.2016.02.005 


\section{ARTTIE $Y$}

Ipplied Reseitrones in Technics, Technologies and Bductition

Journal of the Faculty of Technics and Technologies, Trakia University https://sites.google.com/a/trakia-uni.bg/artte/

[8] Mladenov, M., S. Penchev, M. Deyanov, Complex assessment of food products quality using analysis of visual images, spectrophotometric and hyperspectral characteristics. International Journal of Engineering and Innovative Technology (IJEIT), Vol. 4, Iss. 12, June 2015, ISSN: 2277-3754, pp.23-32.

[9] Onac I., V. Singureanu, G. Moldovan, R. Ungur, High frequency pulsatile electromagnetic fields and ultrasound pulsatile fields impact on germination dynamic of ocimum basilicum L. and $\mathrm{O}$. basilicum var. purpurascens benth observed with Open source software, Not Bot Horti Agrobo, 2016, 44(1), ISSN 1842-4309, pp.41-47.

[10] Online barcode reader - QR Code, DataMatrix, PDF417 and 1D, https://www.dynamsoft.com/Demo/DBR/BarcodeReaderDemo.aspx (available on 26.06.2016).

[11] Paskaleva T., Educational Solutions of new generation in favor of training in health care professionals, Fourth Scientific Session of the Medical College - Sofia, October 2015, Journal "Varna Medical Forum".

[12] Paskaleva T., B. Tornyova, V. Ivanov, Application of interactive presentation systems in the process of training of health care professionals, Jubilee Conference - 20 years specialty "Rehabilitation" Medical College - Stara Zagora, May 2014 (in Bulgarian).

[13] Pencheva A., N. Angelova, L. Jordanova, H. Mitev, Video content generated in QR code - an innovative, interactive teaching method, Proceedings of the V-th National Conference on e-learning in high schools, Publishing center of RU "Angel Kanchev", Rousse, 2014, pp. 241-246, ISBN 978-954-712-611-4 (in Bulgarian).

[14] Power T., R. Gater, C. Grant, N. Winters, Educational Technology Topic Guide, HEART Topic Guides 2014, London: The Health \& Education Advice \& Resource Team.

[15] Shivacheva G., V. Nedeva, Modern aspects of training in programming with virtual laboratory, Education and research in the information society. Proceedings of the National Conference (Plovdiv 26-27 May 2016). ISSN 1314-0752, pp. 197-206 (in Bulgarian).

[16] Stoykova V., A. Smrikarov, A. Ivanova, Kr. Georgieva, N. Ivanova, Interactive devices for educating the students from Digital Generation - an extra or a necessity? , Proceedings of the Fifth National Conference on e-learning in high schools. publishing center of RU "Angel Kanchev", Rousse, 2014, with. 197-207, ISBN 978-954-712-611-4.

[17] Van Horn R., A do-it-yourself document camera, spyware, and Firefox. Phi Delta Kappan, March 2005, 86:487, 551.

[18] Zlatev Z., K. Dobreva, V. Bochev, Analysis of implementation of computer vision system in food technology education, Annual conference of University of Rousse, ISSN 13113321, vol.52, No.10.2, 2013, pp.229-233.

[19] Zlatev Z., J. Ilieva, V. Stoykova, Application of additional devices to the interactive presentation system in Food Technology education, , Proceedings of the $\mathrm{V}$-th National Conference on e-learning in high schools, Publishing center of RU "Angel Kanchev", Rousse, 2014, pp.208-213, ISBN 978-954-712-611-4 (in Bulgarian).

[20] http://bestreviews.com/best-document-cameras (available on 16.06.2016).

[21] http://ipaddocumentcamera.com/pages/justand_(available on 16.06.2016).

[22] http://uk.presentation.aver.com/case-study/Brunel-University-UK (available on 20.05.2016)

[23] http://www.edtechmagazine.com/higher/article/2011/02/education-in-focus (available on 03.07.2016).

[24] http://www.instructables.com/id/Low-cost-document-camera-visualiser/ (available on 26.06.2016).

[25] http://www.instructables.com/id/USB-web-cam-into-class-room-visualiser/ (available on 26.06.2016).

IRTIIL Vol. 4, No. 2, 2016 ISSN 1314-8788 (print), ISSN 1314-8796 (online), doi: 10.15547/artte.2016.02.005 


\section{IRTTIE

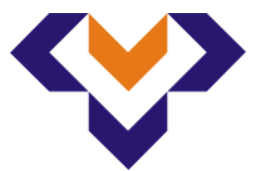 \\ Ipplied Researl ches in Technics, Technologies ind Riducition Journal of the Faculty of Technics and Technologies, Trakia University https://sites.google.com/a/trakia-uni.bg/artte/}

[26] http://www.scholastic.com/browse/article.jsp?id=3752578 (available on 15.05.2016).

[27] http://www.wcax.com/story/31145840/election-officials-in-nh-to-use-cameras-todocument-voters (available on 02.06.2016).

[28] https://sites.google.com/a/jeromeschools.org/ipads-in-the-classroom/using-the-ipad-asa-document-camera (available on 02.06.2016).

[29] https://www.youtube.com/watch?v=0AdayYjW01g (available on 02.06.2016).

IRTTE Vol. 4, No. 2, 2016 ISSN 1314-8788 (print), ISSN 1314-8796 (online), doi: 10.15547/artte.2016.02.005 